\title{
Correction
}

\section{Correction to: Exploring the potential of black gram (Vigna mungo) flour as a fat replacer in biscuits with improved physicochemical, microstructure, phytochemicals, nutritional and sensory attributes}

\author{
Syed Muhammad Ghufran Saeed ${ }^{1} \cdot$ Syed Arsalan Ali $^{1}{ }^{10} \cdot$ Rashida $\mathrm{Ali}^{1,2,3} \cdot$ Syed Asad Sayeed ${ }^{1,2} \cdot$ Lubna Mobin $^{1}$. \\ Raheel Ahmed ${ }^{3}$
}

Published online: 5 February 2021

(c) The Author(s) $2021 \quad$ OPEN

\section{Correction to: SN Applied Science \\ https://doi.org/10.1007/s42452-020-03797-6}

The version of Fig. 5 in the initial online publication was incorrect. The original article has been corrected.

Open Access This article is licensed under a Creative Commons Attribution 4.0 International License, which permits use, sharing, adaptation, distribution and reproduction in any medium or format, as long as you give appropriate credit to the original author(s) and the source, provide a link to the Creative Commons licence, and indicate if changes were made. The images or other third party material in this article are included in the article's Creative Commons licence, unless indicated otherwise in a credit line to the material. If material is not included in the article's Creative Commons licence and your intended use is not permitted by statutory regulation or exceeds the permitted use, you will need to obtain permission directly from the copyright holder. To view a copy of this licence, visit http://creativecommons .org/licenses/by/4.0/.

Publisher's Note Springer Nature remains neutral with regard to jurisdictional claims in published maps and institutional affiliations.

The original article can be found online at https://doi.org/10.1007/s42452-020-03797-6.

Syed Arsalan Ali, 786syedarsalanali@gmail.com | 1 Department of Food Science and Technology, University of Karachi, Main University Road, Karachi, Sindh 75270, Pakistan. ${ }^{2}$ Department of Food Science and Technology, Jinnah Women University, 5C, Block 5 Nazimabad, Karachi City, Sindh 74600, Pakistan. ${ }^{3}$ English Biscuit Manufacturers Private Limited, Karachi, Sindh, Pakistan. 